\title{
Extrazonal steppes of forest belt on eastern macroslope of the Urals
}

\author{
Natalya Zolotareva ${ }^{1, *}$, Andrey Korolyuk ${ }^{2}$ \\ ${ }^{1}$ Institute of Plant and Animal Ecology UB RAS, 620144, 8 Marta Str., 202, Ekaterinburg, Russia \\ ${ }^{2}$ Central Siberian botanical garden SB RAS, 630090, Zolotodolinskaya Str., 101, Novosibirsk, Russia
}

\begin{abstract}
Extrazonal steppes of forest belt on eastern macroslope of the Middle and South Urals have small coenotic diversity. The most part of studied communities are petrophytic steppes on outcrops, which determine regional features of plant cover and provide habitats to rare, endemic and relict plant species. Petrophytic steppes correspond to order HelictotrichoStipetalia, meadow steppes and xeric meadows, shrub thickets correspond to order Brachypodietalia pinnati (class Festuco-Brometea).
\end{abstract}

Extrazonal steppe is characteristic vegetation element of forest belt of the Middle and South Urals. In the Middle Urals the steppes occur on basic and ultrabasic outcrops till the southern boundary of middle taiga. In boreal zone of the South Urals the steppes are found mainly on the hyperbasites of the eastern mountain ranges. The main part of studied communities are petrophytic steppes on outcrops and a little part are meadow steppes and xeric meadows on gentle slopes. The information about steppes of forest belt of the Urals is fragmentary $[1,2,3]$. The aim of our research was to investigate the diversity of extrazonal steppe communities of forest belt of the Urals on the territory of Sverdlovsk and Chelyabinsk Regions. The dataset includes 595 relevés collected in the forest belt of the Middle and South Urals. All relevés were classified using JUICE 7.0. The dataset presents 9 types of communities which differ in species composition and set of dominants; activity of species was calculated for each type of community. The first four clusters unify meadow steppes and xeric meadows, shrub thickets, the remaining clusters are petrophytic steppes.

Clusters:

1. Meadow steppes on deep soils of lower parts of slopes (the Middle Urals). Species of meadow steppes: Filipendula vulgaris, Fragaria viridis, Poa angustifolia, Stipa pennata. Meadow steppes are differentiated by species of dry meadows and thermophytic forest edges (Astragalus danicus, Centaurea scabiosa, Galium album, Gentiana cruciata, Knautia arvensis, Leucanthemum vulgare, Plantago media, Potentilla argentea, Trifolium pratense), creating the core of communities. Cluster includes communities of ass. Leucanthemo vulgaris-Stipetum pennatae Bayanov in Yamalov et al. 2013 [4].

2. Meadow steppes on shallow soils of stony slopes surrounded by forest (the Middle Urals). They are differentiated by species of forest edges (Brachypodium pinnatum, Pinus sylvestris, Rubus saxatilis) and petrophytic steppes (Centaurea sibirica, Echinops crispus). Stipa pennata and Helictotrichon desertorum usually dominate, sometimes Calamagrostis

* Corresponding author: nvp@,ipae.uran.ru 
arundinacea, C. epigeios, Centaurea sibirica and Brachypodium pinnatum take their place. Cluster includes communities of ass. Pulsatillo uralensis-Helictotrichetum desertorum Teptina et al. 2018 (subass. P.u.-H.d. calamagrostietosum arundinaceae and subass. P. u.H. d. calamagrostietosum epigeii,var. Stipa dasyphylla).

3. Meadow steppes on shallow soils of middle and lower parts of stony slopes (the South Urals). They are differentiated by species of forest edges (Hylotelephium triphyllum), meadow steppes (Artemisia latifolia, A. sericea, Cerastium arvense, Galatella angustissima, Helictotrichon schellianum) and petrophytic steppes (Eremogone micradenia, Silene repens, Thalictrum foetidum). Species of meadow steppes (Artemisia sericea, Fragaria viridis, Stipa pennata, Helictotrichon desertorum) and species of forest edges Calamagrostis epigeios dominate.

4. Shrub thickets (the Middle and South Urals). Species of forest edges (Aconogonon alpinum, Campanula bononiensis, Nepeta pannonica, Vicia tenuifolia) differentiate shrub thickets; Cerasus fruticosa, Rosa majalis, Spiraea crenata have high activity. Spiraea crenata is the key dominant, sometimes Cerasus fruticosa accompanies it. Thickets of steppe shrubs occupy a large area in the forest belt of the South Urals, in the Middle Urals they make small patches.

5. Petrophytic variants of meadow steppes (the Middle Urals). These widespread communities do not have any differential species. They occur on slope outcrops surrounded by forest. The species of petrophytic steppes (Centaurea sibirica, Echinops crispus, Helictotrichon desertorum, Onosma simplicissima), typical steppes (Festuca valesiaca) and meadow steppes (Stipa pennata) have high activity in these communities. They belong to ass. Stipo pennatae-Centauretum sibiricae Yamalov et al. 2013 nom. invalid., ass. Pulsatillo uralensis-Helictotrichetum desertorum, and community Thymus uralensis-Dianthus acicularis [3].

6. Petrophytic variants of meadow steppes (the South Urals). These communities occupy outcrops on the upper and middle parts of slopes. High activity of petrophytes (Clausia aprica, Lychnis sibirica, Scorzonera glabra) differ them from the communities of previous cluster: they are diagnostic species of ass. Stipo pennatae-Centauretum sibiricae in this communities.

7. Xerophytic outcrop communities (the Middle Urals). Petrophytes Alyssum obovatum and Vincetoxicum albowianum have high activity. Diagnostic species of class FestucoBrometea Br.-Bl. et Tx. ex Soó 1947 (Festuca valesiaca, Galium verum, Phleum phleoides, Veronica spicata) are also active.

8. Petrophytic steppes dominated by Stipa capillata and Festuca valesiaca (the Middle and South Urals). The communities of steep rocky slopes are differentiated by species of forest edges (Potentilla argentea), meadow steppes (Achillea nobilis, Thymus marschallianus) and typical steppes (Stipa capillata, Verbascum phoeniceum). The high activity of petrophytes (Artemisia frigida, Dianthus acicularis, Echinops crispus, Koeleria cristata, Thymus punctulosus, Veronica spicata) is a distinctive feature of these communities.

9. Petrophytic communities of riverbank outcrops (the Middle Urals). Petrophytes (Schivereckia hyperborea, Minuartia krascheninnikovii) and species of steppes and ruderal habitates (Dracocephalum thymiflorum) characterize them. Petrophytes (Elytrigia reflexiaristata, Aster alpinus, Carex pediformis) and weed Arenaria serpyllifolia have high activity. Relevés include diagnostic species of class Festuco-Brometea (Campanula sibirica, Festuca valesiaca, Veronica spicata) and order Helictotricho-Stipetalia Toman 1969 (Helictotrichon desertorum, Potentilla humifusa).

Cluster analysis revealed 2 group of communities (Fig.). Group A brings together meadow steppes, xeric meadows, and shrub thickets; it corresponds to order Brachypodietalia pinnati widespread in Europe [5]. The group B includes petrophytic 
steppes, and corresponds to order Helictotricho-Stipetalia (typical steppes and more xeric variants of meadow steppes of Urals, Northern Kazakhstan and West Siberia [6].

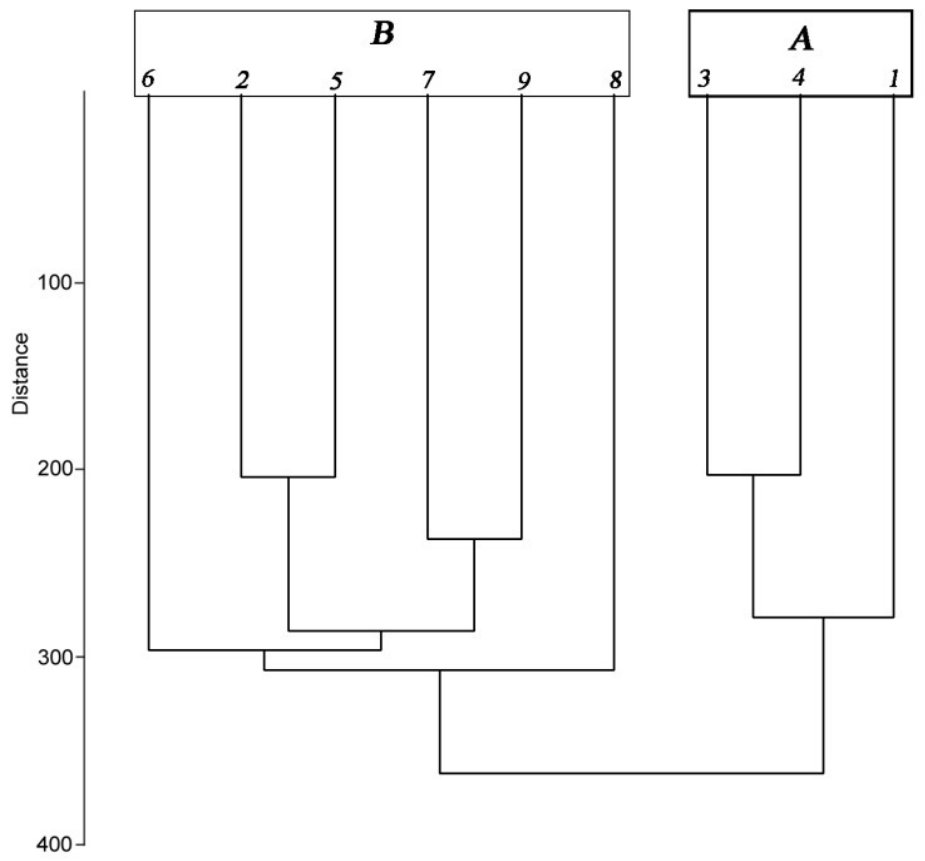

Fig. Cluster analysis (algorithm UPGMA, similarity index Euclidean distance). A - the order Brachypodietalia pinnati, B - the order Helictotricho-Stipetalia, 1-9 - correspond to communities in the text.

The studied vegetation has low coenotic diversity. The most part of meadow steppes and xeric meadows communities correspond to ass. Leucanthemo vulgaris-Stipetum pennatae. Petrophytic steppes determine regional features of plant cover and provide habitats to rare, endemic and relict plant species. The main part of petrophytic communities belongs to ass. Stipo pennatae-Centauretum sibiricae; some new syntaxa can be revealed. Many petrophytic communities of Sverdlovsk Region are included in nature monuments or are promising for organization of protected areas [7]. Petrophytic steppes of the boreal zone in the South Urals are protected only in Ilmensky Reserve whereas petrophytic communities of Vishnevye and Potaniny, Sugomak, Egozinskaya mountains are rich in rare plant species, one of them is local endemic Oxytropis ponomarjevii. Protected areas should be organized to preserve steppe vegetation in these habitats $[2,8]$.

This research was funded by RFBR according to the research project № 17-04-00276, as well as within the framework of the state task of the Institute of Plant and Animal Ecology.

\section{References}

1. V.B. Sochava, Sov. Bot., 13, № 3 (1945)

2. P.L. Gorchakovskii, N.V. Zolotareva, Russian Journal of Ecology, 37, 6 (2006)

3. A.Y. Teptina, M.V. Lebedeva, S.M. Yamalov, Veg. Russ, 33 (2018) 
4. S.M. Yamalov, A.V. Bayanov, A.A. Muldashev, E.A. Averinova, Veg. Russ, 22 (2011)

5. W. Willner et al., Appl. Veg. Sci., 20 (1) (2017)

6. A.Yu. Korolyuk, Veg. Russ., 30 (2017)

7. N.V. Zolotareva, E.N. Podgaevskaya, Izvestia RAS SamSC, 14, 1 (4) (2012)

8. N.V. Zolotareva, Mountain Ecosystems and Their Components, 2 (2007) 